\title{
Autoimmune Encephalitis Resembling Dementia Syndromes
}

Anna E.M. Bastiaansen, MD, Robin W. van Steenhoven, MD, Marienke A.A.M. de Bruijn, MD, Yvette S. Crijnen, MD, Agnes van Sonderen, MD, PhD, Marleen H. van Coevorden-Hameete, MD, PhD, Marieke M. Nühn, MSc, Marcel M. Verbeek, PhD, Marco W.J. Schreurs, PhD, Peter A.E. Sillevis Smitt, MD, PhD, Juna M. de Vries, MD, PhD, Frank Jan de Jong, MD, PhD, and Maarten J. Titulaer, MD, PhD

Neurol Neuroimmunol Neuroinflamm 2021;8:e1039. doi:10.1212/NXI.0000000000001039

\section{Abstract \\ Objective}

As autoimmune encephalitis (AIE) can resemble neurodegenerative dementia syndromes, and patients do not always present as encephalitis, this study evaluates how frequently AIE mimics dementia and provides red flags for AIE in middle-aged and older patients.

\section{Methods}

In this nationwide observational cohort study, patients with anti-leucine-rich gliomainactivated 1 (LGI1), anti-NMDA receptor (NMDAR), anti-gamma-aminobutyric acid $B$ receptor $\left(G_{A B A} R\right)$, or anti-contactin-associated protein-like 2 (CASPR2) encephalitis were included. They had to meet 3 additional criteria: age $\geq 45$ years, fulfillment of dementia criteria, and no prominent seizures early in the disease course ( $\leq 4$ weeks).

\section{Results}

Two-hundred ninety patients had AIE, of whom 175 were 45 years or older. Sixty-seven patients (38\%) fulfilled criteria for dementia without prominent seizures early in the disease course. Of them, 42 had anti-LGI1 (48\%), 13 anti-NMDAR (52\%), 8 anti-GABA $\mathrm{B}$ (22\%), and 4 anti-CASPR2 (15\%) encephalitis. Rapidly progressive cognitive deterioration was seen in 48 patients $(76 \%)$, whereas a neurodegenerative dementia syndrome was suspected in half $(\mathrm{n}=$ 33). In 17 patients (27\%; 16/17 anti-LGI1), subtle seizures had been overlooked. Sixteen patients $(25 \%)$ had neither inflammatory changes on brain MRI nor CSF pleocytosis. At least 1 CSF biomarker, often requested when dementia was suspected, was abnormal in 27 of 44 tested patients $(61 \%)$, whereas 8 had positive $14-3-3$ results (19\%). Most patients (84\%) improved after immunotherapy.

\section{Conclusions}

Red flags for AIE in patients with suspected dementia are: (1) rapidly progressive cognitive decline, (2) subtle seizures, and (3) abnormalities in ancillary testing atypical for neurodegeneration. Physicians should be aware that inflammatory changes are not always present in AIE, and that biomarkers often requested when dementia was suspected (including 14-3-3) can show abnormal results. Diagnosis is essential as most patients profit from immunotherapy.
Correspondence

Dr. Titulaer

m.titulaer@erasmusmc.nl
MORE ONLINE

(4) Infographic

http://links.lww.com/NXI/ A561

From the Department of Neurology (A.E.M.B., R.W.v.S., Y.S.C., M.H.v.C.-H., P.A.E.S.S., J.M.d.V., M.J.T.), Erasmus MC University Medical Center, Rotterdam; Department of Neurology, VU University Medical Center, Amsterdam (R.W.v.S.); Department of Neurology (M.A.A.M.d.B.), Elisabeth Tweesteden Medical Center, Tilburg; Department of Neurology (A.v.S.), Haaglanden Medical Center, The Hague; Honours Student Bachelor Biomedical Sciences (M.M.N.), University Utrecht; Department of Neurology and Laboratory Medicine (M.M.V.), Donders Institute for Brain Cognition and Behavior, Radboud University Medical Center, Nijmegen; Department of Immunology (M.W.J.S.), Erasmus MC University Medical Center, Rotterdam; and Alzheimer Center Erasmus MC (F.J.d.J.), Department of Neurology, Erasmus MC University Medical Center, Rotterdam, the Netherlands. 


\section{Glossary}

$\mathbf{A} \mathbf{3 4 2}=$ amyloid-beta-42; $\mathrm{AD}=$ Alzheimer dementia; $\mathrm{ADL}=$ activity of daily living; AIE $=$ autoimmune encephalitis; CASPR2 = contactin-associated protein-like 2; CBA = cell-based assay; CJD = Creutzfeldt-Jakob disease; $\mathbf{D W I}=$ diffusion-weighted imaging; FBDS = faciobrachial dystonic seizures; FDG-PET = 18fluorodeoxyglucose PET; GABABR = gamma-aminobutyric acid $\mathrm{B}$ receptor; $\mathbf{I g}=$ immunoglobulin; $\mathbf{I Q R}=$ interquartile range; $\mathbf{I S O}=$ International Organization for Standardization; LGI1 = leucine-rich glioma-inactivated $1 ; \mathbf{m R S}=$ modified Rankin scale; NMDAR = NMDA receptor; $\mathbf{p}$-tau = phosphorylated tau; $\mathbf{R P D}=$ rapidly progressive dementia; $\mathbf{R T}-\mathbf{Q u I C}=$ real-time quaking-induced conversion; $\mathbf{t}$-tau $=$ total tau.

Autoimmune encephalitis (AIE) comprises a group of antibodymediated inflammatory brain diseases. Binding of these antibodies to extracellular epitopes of neuronal structures leads to cerebral dysfunction. Diagnostic criteria for AIE help to select patients for antibody testing. These criteria are characterized by a subacute deterioration of cognition, altered mental status, or psychiatric symptoms. These symptoms should be accompanied by seizures, new findings of focal involvement of the CNS, or inflammatory changes in the CSF (pleocytosis) or on brain MRI. ${ }^{1}$ Anti-leucine-rich glioma-inactivated 1 (LGI1), antiNMDA receptor (NMDAR), anti-gamma-aminobutyric acid B receptor $\left(\mathrm{GABA}_{\mathrm{B}} \mathrm{R}\right)$, or anti-contactin-associated protein-like 2 (CASPR2) antibodies are the most common antibodies causing AIE, and cognition is frequently affected in all these AIE subtypes. $^{2-5}$

Diagnosing AIE can be challenging because patients can present with less notable encephalitis signs. The disease course can mimic neurodegenerative dementia syndromes. Rapid progression is often expected, but slower progression has also been described, resulting in misdiagnosis or treatment delay leading to a worse outcome. ${ }^{5-10}$ It is unknown how often AIE resembles dementia syndromes. ${ }^{11,12}$ In patients presenting with a possible dementia, clinical clues are essential for physicians to avoid misdiagnosis and inadvertently withhold patients from immunotherapy.

The study aim was to evaluate possible dementia diagnosis and to describe red flags for AIE in middle-aged and older patients with anti-LGI1, anti-NMDAR, anti-CASPR2, and anti-GABA $A_{B} R$ encephalitis.

\section{Methods}

\section{Patients}

We performed a nationwide observational cohort study in middleaged and older patients with anti-LGIl, anti-NMDAR, anti$\mathrm{GABA}_{\mathrm{B}} \mathrm{R}$, and anti-CASPR2 encephalitis. The Department of Neurology of the Erasmus University Medical Center is the national referral site for patients with suspected AIE, and the Laboratory of Medical Immunology is the International Organization for Standardization (ISO) 15189-accredited national referral site for antineuronal antibody testing. Patients were identified between August 1999 and September 2019, although 87\% were identified after 2010. All Dutch patients with AIE with anti-LGI1, anti-NMDAR, anti-GABA $A_{B} R$, or anti-CASPR2 antibodies were asked to participate. ${ }^{3-5,13}$ Antibodies were detected in serum, or in the CSF using validated commercial cell-based assays (CBAs), and were confirmed with in-house CBA, immunohistochemistry, or live hippocampal neurons as described before. ${ }^{3,5,14,15}$ Only patients who were 45 years or older at disease onset were included, as the main challenge to discriminate between AIE and neurodegenerative dementia is within this age group (Figure 1).

In addition to the tests that were performed in the diagnostic workup, CSF markers that often requested when dementia was suspected (total tau [t-tau], phosphorylated tau-181 [p-tau], and 14-3-3) were determined in all patients with sufficient available CSF $(n=12)$, in the ISO 15189-accredited laboratory at the Radboud UMC. ${ }^{16}$ Levels of t-tau and p-tau were measured using ELISAs (Fujirebio, Ghent, Belgium). From February 2019, a semiautomated version of the same ELISAs using Lumipulse (Fujirebio, Ghent, Belgium) was used. 14-3-3 was analyzed using Western blotting as previously described ${ }^{17}$ Furthermore, patients with a positive 14-3-3 and sufficient available CSF were post hoc tested for real-time quaking-induced conversion (RT-QuIC). ${ }^{18}$ All values were scored according to the reference values at the time of testing and adjusted to current cutoff values in the figure for ease of comparison. Cutoff values to be considered abnormal were t-tau $>400 \mathrm{pg} / \mathrm{mL}$, p-tau $>64 \mathrm{pg} / \mathrm{mL}$, amyloid-beta- 42 $(\mathrm{A} \beta 42)<500 \mathrm{pg} / \mathrm{mL}$, a t-tau/p-tau ratio $>30$, and a t-tau/A $\beta 42$ ratio $>0.52$. A positive 14-3-3 or RT-QuIC was also abnormal. Based on these CSF markers, patients had a Creutzfeldt-Jakob disease (CJD) profile if the $\mathrm{t}$-tau/p-tau ratio was abnormal, and an Alzheimer dementia $(\mathrm{AD})$ profile was assigned when $\mathrm{A} \beta 42$ was lowered or the $\mathrm{t}$-tau/A 442 ratio was abnormal. ${ }^{19}$

MRIs were reviewed at our site by neuroradiologists in most cases visiting our center, whereas in patients with LGI1 antibodies MRIs were scored by an independent neuroradiologist as published before. ${ }^{3}$ In the remaining patients, radiographic outcomes were based on the radiology reports.

\section{Clinical Phenotype and Dementia Criteria}

Clinical patient data were retrieved during a visit to our clinic in $48 \%$, from telephone interviews with patients or relatives in $31 \%$, and from medical files in $21 \%$. The clinical disease course was assessed for fulfillment of the 2011 NINCDSADRDA criteria for dementia. ${ }^{20}$ These internationally accepted core clinical criteria can be used for the diagnosis of all-cause dementia. Dementia is diagnosed when there are cognitive or behavioral symptoms that (1) interfere with the 
ability to function at work or at usual activities; (2) represent a decline from previous levels of functioning and performing; (3) are not explained by delirium or major psychiatric disorder; (4) cognitive impairment is detected and diagnosed through a combination of history-taking and a cognitive assessment; and (5) the cognitive or behavioral impairment involves a minimum of 2 of the following domains: (a) impaired ability to acquire and remember new information; (b) impaired executive functions; (c) impaired visuospatial abilities; (d) impaired language functions; and (e) changes in personality, behavior, or comportment. ${ }^{20}$ Rapidly progressive dementia (RPD) was defined as fulfillment of the dementia criteria within 12 months or death within 2 years after the appearance of the first cognitive symptoms. ${ }^{21}$

In addition, we excluded patients with prominent seizures early in the disease course ( $\leq 4$ weeks) because this is less likely in neurodegenerative dementia syndromes, and physicians will already suspect inflammatory causes. Subtle seizures that remained unnoticed by the treating physician were not covered by these additional criteria.

Level of functioning was measured with the modified Rankin scale (mRS), ${ }^{22}$ and in most patients, we had direct contact to obtain $\mathrm{mRS}$ scores. Cognitive domains were assessed by 2 persons independently reviewing all clinical charts, using neuropsychological assessments, Mini-Mental State Examinations, and Montreal Cognitive Assessments when available.

\section{Statistics}

Categorical data were compared using the Fisher-FreemanHalton test. Continuous data were analyzed using one-way analysis of variance with log-transformation because of skewed distribution (age at disease onset and delay until initiation of treatment after disease onset) and the KruskalWallis test (days between the onset and start of seizures, days to cognitive decline after disease onset, duration of follow-up, and $\mathrm{mRS}$ at follow-up). To assess multiple testing, $p$ values below 0.005 were considered significant. Values between 0.05 and 0.005 should be interpreted carefully and considered exploratory. Post hoc analysis to evaluate differences between antibody types was assessed using the same statistical tests, corrected by the Holm method. We used SPSS 25.0 (SPSS Inc., Chicago, IL) for Windows for statistical analysis, as well as Prism 8.4.3 (GraphPad, San Diego, CA).

\section{Standard Protocol Approvals, Registrations, and Patient Consents}

This study was approved by the Institutional Review Board of the Erasmus MC. Written informed consent was obtained from all patients.

\section{Data Availability}

Any data not published within this article are available at the Erasmus MC University Medical Center. Patient-related data will be shared on reasonable request from any qualified investigator, maintaining anonymization of the individual patients.

\section{Results}

\section{Patient Characteristics}

In total, 290 patients with AIE were identified, of whom 95 patients harbored LGI1 antibodies, 132 NMDAR antibodies, $37 \mathrm{GABA}_{\mathrm{B}} \mathrm{R}$ antibodies, and $26 \mathrm{CASPR} 2$ antibodies. At disease onset, 175 of the patients $(60 \%)$ had an age of $\geq 45$ years,

Figure 1 Patient Inclusion

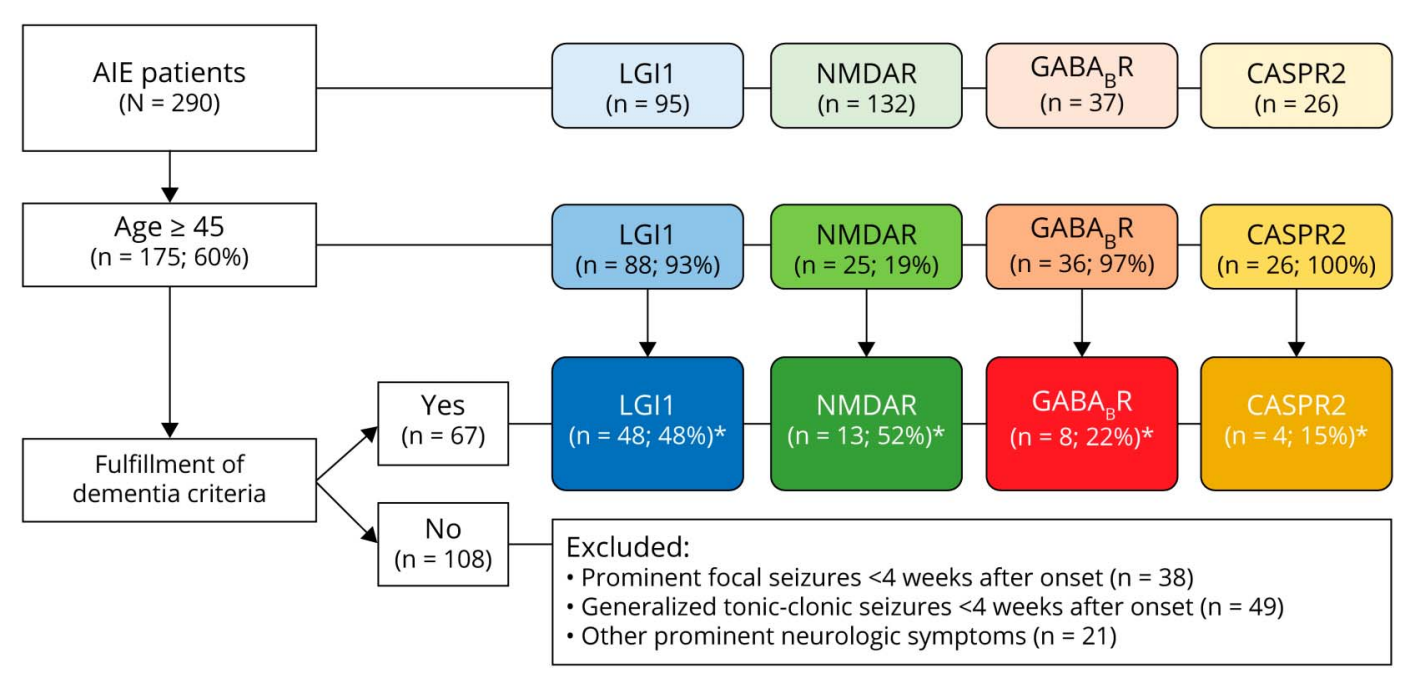

In total, 290 patients with autoimmune encephalitis were identified. At disease onset, 175 of the patients had an age of $\geq 45$ years. Sixty-seven patients fulfilled the dementia criteria including the additional condition that no prominent seizures were present at early disease course ( $\leq 4$ weeks). $*$ Percentage of the patients $\geq 45$ years of age. AIE = autoimmune encephalitis; CASPR2 = contactin-associated protein-like 2; GABA $\mathrm{B}=$ gamma-aminobutyric acid B receptor; LGI 1 $=$ leucine-rich glioma-inactivated $1 ;$ NMDAR = NMDA receptor. 
including 88 LGI1 (93\%), 25 NMDAR (19\%), 36 GABA $_{B} R$ (97\%), and 26 CASPR2 (100\%) encephalitis patients. These patients were assessed for fulfillment of the dementia criteria including the additional condition that no prominent seizures were present at early disease course. Sixty-seven patients fulfilled these criteria (39\%): 42 LGI1 (48\%), 13 NMDAR (52\%), $8 \mathrm{GABA}_{\mathrm{B}} \mathrm{R}(22 \%)$, and 4 CASPR2 (15\%) encephalitis patients (Figure 1). Patients who had no very rapid onset (only fulfilling dementia criteria beyond 3 months) and had neither MRI abnormalities nor CSF pleocytosis were highlighted in eFigure 1 and eTable 1 (links.lww.com/NXI/A535), as these pose the largest challenge. The patients with CASPR2 encephalitis were excluded from statistical analysis (because of the small number) and described exploratively in the supplementary text.

Of the remaining 63 patients with anti-LGI1, anti-NMDAR, and anti-GABA $A_{B}$ R encephalitis, 37 were male (58\%; Table 1). In anti-LGI1 encephalitis, there was a trend toward a male predominance compared with the higher frequency of females in anti-NMDAR encephalitis $\left(p_{\text {uncorrected }}=0.047\right)$. The median age at onset was 64 years (interquartile range [IQR] 58-72, range 48-85).

Almost all patients had cognitive deterioration $(\mathrm{n}=62,98 \%)$ and behavioral changes $(n=55,87 \%)$.

Cognitive decline was the presenting symptom in most patients ( $n=48,76 \%$; median time to cognitive decline 0 days). There was a rapidly progressive deterioration of cognitive symptoms in 48 patients ( $76 \%$ ), and 5 patients were admitted to a closed psychogeriatric ward. In half of the patients $(\mathrm{n}=$ $33,52 \%$ ), a neurodegenerative dementia syndrome was suspected by the treating physician.

Cognitive domains were affected differently in the various AIE subtypes (Figure 2). Patients with anti-LGI1 or anti-GABA $A_{B} R$ encephalitis had similarities with more prominent and more frequently severe impairment of visuospatial and executive functions ( $\sim 70 \%$ in LGI1 and 55\% in $\mathrm{GABA}_{\mathrm{B}}$ R encephalitis). By contrast, patients with anti-NMDAR encephalitis more frequently had impaired language functions $(85 \%, p<$ $0.0001)$, and behavioral changes were more prominent.

Sleep-related problems were most frequent in anti-LGI1 encephalitis $(57 \%, p=0.004)$. In anti-NMDAR encephalitis, patients experienced, besides the speech problems, more movement disorders $\left(46 \%, p_{\text {uncorrected }}=0.009\right.$; eTable 1 and eTable 2, links.lww.com/NXI/A535).

There were no prominent seizures early ( $\leq 4$ weeks) in the disease course (exclusion criterion). If prominent seizures were present, these occurred after a median of 3 months (IQR 42-181 days). However, 40 patients (64\%) developed seizures during the course of the disease. Looking scrutinously, actually 11 of 40 patients with seizures (28\%) had developed subtle seizures within 2 weeks after disease onset.
However, in all patients, these were initially missed faciobrachial dystonic seizures (FBDS) or nonmotor subtle focal seizures. In total, subtle seizures were overlooked in a quarter of the patients $(n=17)$. Most subtle seizures were seen in anti-LGIl encephalitis $(n=16)$ compared with the other AIE subtypes $\left(p_{\text {uncorrected }}=0.011\right)$.

\section{Ancillary Testing}

Ancillary testing showed normal routine CSF results (white blood cell count, total protein, and, if performed, immunoglobulin (Ig) G index and oligoclonal bands) and no abnormalities related to AIE (hyperintensities of the mesial temporal lobe) on MRI T2/fluid-attenuated inversion recovery in half of the patients ( $53 \%$ and $54 \%$, respectively). In 16 of 61 patients (25\%), neither CSF pleocytosis nor MRI inflammatory changes were found. In anti-LGI1, CSF was even more frequently normal $(76 \%, p<0.0001)$. In all patients, atrophy was rarely seen on initial MRI $(n=4)$, and no abnormalities on diffusion-weighted imaging (DWI) were reported. EEG showed epileptic discharges in 13 patients (23\%), and in 25 patients (45\%), the EEG was normal, similar between AIE subtypes. Tumor screening resulted in malignancies in 10 patients (17\%), and as expected, in patients with $\mathrm{GABA}_{\mathrm{B}} \mathrm{R}$ antibodies, this was most frequent $(57 \% ; p=0.004)$. Only 2 patients underwent ${ }^{18}$ fluorodeoxyglucose PET (FDGPET) of the brain: one showed hypometabolism in the right caudate area, whereas the other was normal.

CSF biomarkers ( $\mathrm{t}$-tau, $\mathrm{p}$-tau, and $\mathrm{A} \beta 42$ ) were tested in 44 patients (A $\beta 42$ only in 29; Figure 3). A high t-tau was seen in 19 patients (45\%), a high p-tau in 6 patients (16\%), and a low A $\beta 42$ in 12 patients (41\%). A high t-tau/p-tau ratio $(>30$; suggestive for CJD) was present in 6 of 38 patients (16\%), and 14-3-3 was (weakly) positive in 8 of 42 patients (19\%). Five patients with a positive 14-3-3 had been tested by RT-QuIC, and all tested negative. In anti-GABA $A_{B} R$ encephalitis, the 143-3 test was most often found positive, but this was not significantly different compared with other AIE subtypes. The clinical profile of the patients with AIE with a high $\mathrm{t}$-tau or high $\mathrm{t}$-tau/A $\beta 42$ is shown in eTable 3 (links.lww.com/NXI/ A535). Based on these CSF markers that are often requested when dementia was suspected, 14 patients were considered to have a CSF profile suitable for Alzheimer disease or CJD.

We could not identify significant differences between patients with and without RPD, except for the obvious time to dementia (data not shown).

\section{Treatment and Outcome}

The median mRS at onset was 3 (IQR 3-4; 3\% activity of daily living $[\mathrm{ADL}]$ independent), and patients were admitted to the ICU in $16 \%$ of the total cohort (Table 2). Most patients ( $\mathrm{n}=59,94 \%)$ were treated with first-line immunotherapy (combination of IV methylprednisolone or IVIgs). Nine patients $(14 \%)$ received additional second-line immunotherapy (rituximab or cyclophosphamide). In 4 of 8 patients with anti$\mathrm{GABA}_{\mathrm{B}} \mathrm{R}$ encephalitis, no immunotherapy was administered. 
Table 1 Patient Characteristics

\begin{tabular}{|c|c|c|c|c|c|}
\hline & Total & LGI1 $(n=42)$ & NMDAR $(n=13)$ & $\operatorname{GABA}_{B} R(n=8)$ & $p$ Value $^{a}$ \\
\hline Gender, male & $37(58)$ & $29(69)$ & $4(31)$ & $4(50)$ & $0.047 *$ \\
\hline Age at onset & $64(58-72,48-85)$ & $66(59-72,49-82)$ & $61(57-68,48-73)$ & $\begin{array}{l}73(58-76 \\
55-85)\end{array}$ & 0.11 \\
\hline \multicolumn{6}{|l|}{ Cognition characteristics } \\
\hline Cognitive symptoms & $62(98)$ & $41(98)$ & $13(100)$ & $1(100)$ & 1.00 \\
\hline $\begin{array}{l}\text { Median days to cognitive decline } \\
\text { after disease onset }\end{array}$ & $0(0-0,0-176)$ & $0(0-8,0-176)$ & $0(0-0,0-7)$ & $0(0-0,0-0)$ & 0.180 \\
\hline Cognitive decline presenting symptom & $48(76)$ & $30(71)$ & $11(85)$ & $7(88)$ & 0.55 \\
\hline RPD & $48(76)$ & $33(79)$ & $11(85)$ & $4(50)$ & 0.24 \\
\hline Dementia suspected by the treating physician & $33(52)$ & $21(50)$ & $7(54)$ & $5(63)$ & 0.87 \\
\hline Dementia markers tested & $44(65)$ & $27(64)$ & $9(69)$ & $5(56)$ & \\
\hline \multicolumn{6}{|l|}{ Symptoms (during the disease course) } \\
\hline Behavioral changes & $55(87)$ & $35(83)$ & $13(100)$ & $7(88)$ & 0.25 \\
\hline Speech problems & $17(27)$ & $5(14)$ & $11(85)$ & $1(13)$ & $<0.0001 * * *$ \\
\hline Movement disorders & $12(19)$ & $4(10)$ & $6(46)$ & $2(25)$ & $0.009 *$ \\
\hline Awareness problems & $4(6)$ & 0 & $3(23)$ & $1(13)$ & $0.010 *$ \\
\hline Autonomic symptoms & $15(24)$ & $12(29)$ & $3(23)$ & 0 & 0.29 \\
\hline Sleep disorders & $27(43)$ & $24(57)$ & $2(15)$ & $1(13)$ & $0.004 * *$ \\
\hline \multicolumn{6}{|l|}{ Epilepsy } \\
\hline Seizures during the disease course & $40(64)$ & $32(76)$ & $3(23)$ & $5(63)$ & $0.002 * *$ \\
\hline $\begin{array}{l}\text { Days between the onset and start of prominent } \\
\text { seizures }\end{array}$ & $\begin{array}{l}95(42-181 \\
30-1,098)\end{array}$ & $\begin{array}{l}117(60-183 \\
30-1,095)\end{array}$ & $\begin{array}{l}221(34-409, \\
34-409)\end{array}$ & $\begin{array}{l}52(38-85 \\
37-93)\end{array}$ & 0.44 \\
\hline Subtle seizures early in the disease course & $17(27)$ & $16(38)$ & 0 & $1(13)$ & $0.011 *$ \\
\hline \multicolumn{6}{|l|}{ Ancillary testing } \\
\hline Routine CSF normal ${ }^{b}$ & $31 / 58(53)$ & $29 / 38(76)$ & $2 / 13(15)$ & $0 / 7$ & $<0.0001 * * *$ \\
\hline WBC elevated & $21 / 58(36)$ & $5 / 38(13)$ & $11 / 13(85)$ & $5 / 7(71)$ & \\
\hline Total protein elevated & $18 / 55(33)$ & $6 / 38(16)$ & $6 / 12(50)$ & $3 / 5(60)$ & \\
\hline IgG index elevated & $9 / 18(50)$ & $4 / 9(44)$ & $2 / 5(40)$ & $3 / 4(75)$ & \\
\hline Oligoclonal bands present & $5 / 9(56)$ & $0 / 3$ & $2 / 3(67)$ & $3 / 3(100)$ & \\
\hline MRI mesiotemporal hyperintensities & $30 / 62(48)$ & $24 / 41(60)$ & $2 / 13(15)$ & $4 / 8(50)$ & $0.023 *$ \\
\hline EEG abnormal & $31 / 56(55)$ & $21 / 38(55)$ & $6 / 12(50)$ & $4 / 6(67)$ & 0.84 \\
\hline Encephalopathic & $28(50)$ & $18(49)$ & $6(50)$ & $4(67)$ & \\
\hline Epileptic & $13(23)$ & $9(24)$ & $3(25)$ & $1(17)$ & \\
\hline Encephalopathic and epileptic & $10(18)$ & $6(16)$ & $3(25)$ & $1(17)$ & \\
\hline Tumor & $10 / 60(17)$ & $3 / 40(8)$ & $3 / 13(23)$ & $4 / 7(57)^{c}$ & $0.004^{* *}$ \\
\hline \multicolumn{6}{|c|}{ 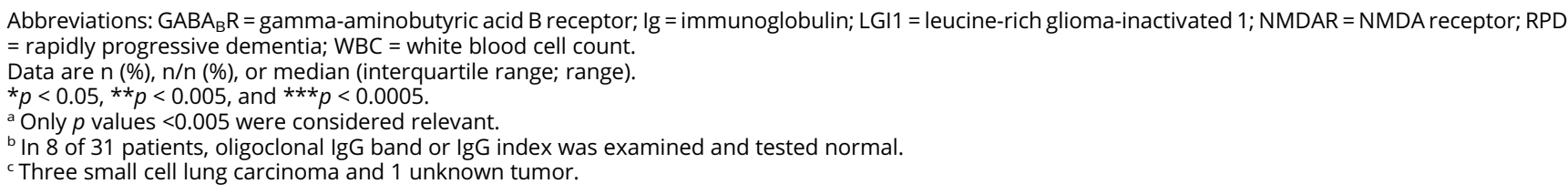 } \\
\hline
\end{tabular}




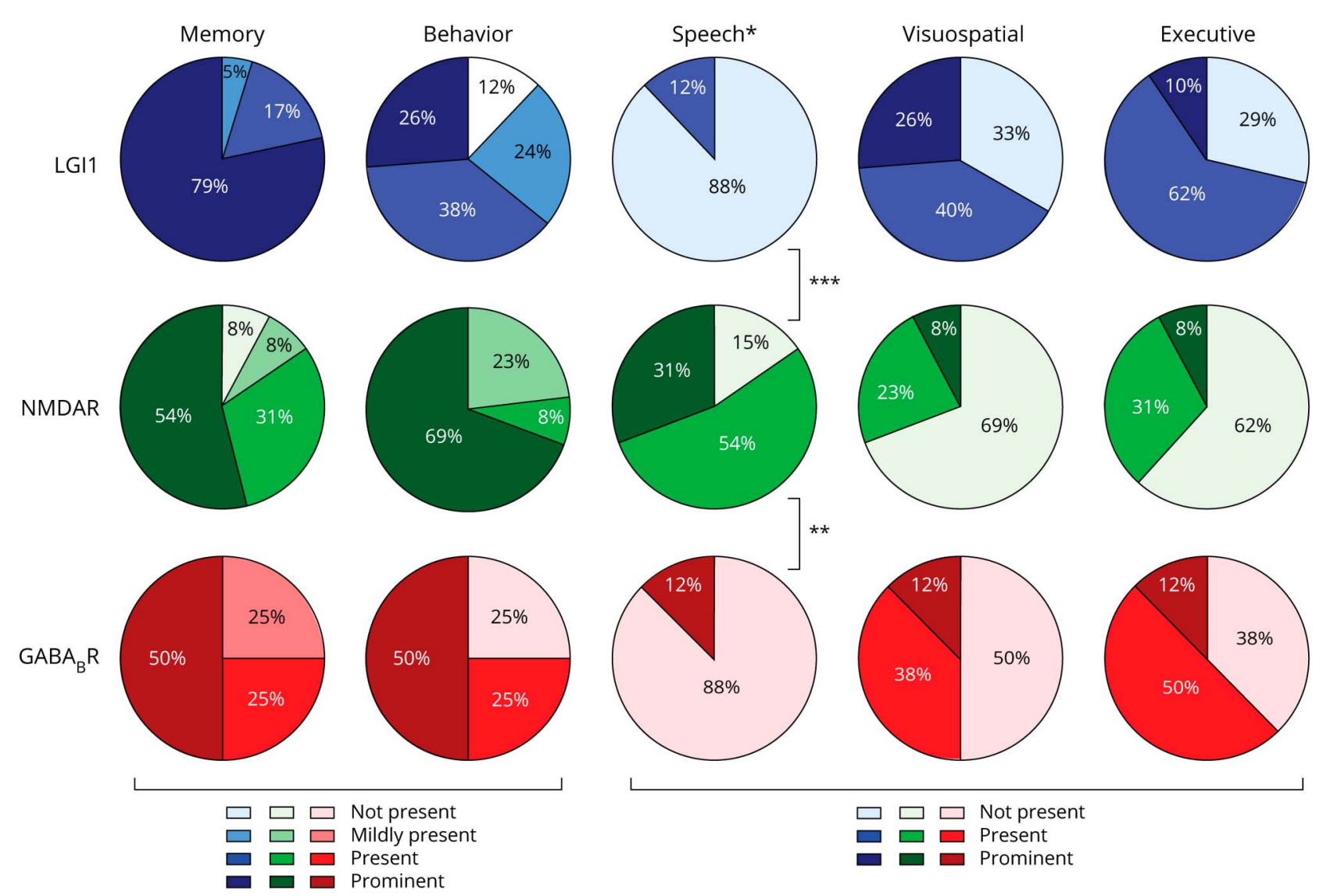

For patients with anti-LGI1, anti-NMDAR, and anti-GABA ${ }_{B}$ encephalitis, cognitive symptoms were divided into 5 cognitive domains. The domains for memory and behavior were divided into 4 categories (not present, mildly present, present, and prominent), and the speech, visuospatial, and executive domains were divided into 3 categories (not present, present, and prominent). $* \star * p<0.0001$ and $* \star p=0.001$ between anti-NMDAR and, respectively, anti-LGI1 and anti$\mathrm{GABA}_{\mathrm{B}} \mathrm{R} . \mathrm{GABA} \mathrm{B}=$ gamma-aminobutyric acid B receptor; LGI1 = leucine-rich glioma-inactivated 1; NMDAR = NMDA receptor.

Two of these patients received chemotherapy for small cell lung carcinoma, and the remaining 2 were postmortem diagnosed as anti-GABA $\mathrm{B}$ encephalitis. In patients with antiNMDAR encephalitis, second-line immunotherapy was administered more frequently $(39 \%, p=0.005)$.

The median delay until initiation of treatment after disease onset was 99 days (IQR 32-219).

To analyze the effects of treatment delay, without interference of the antibody subtype, we assessed treatment in the largest AIE subtype (anti-LGI encephalitis). Patients with a longer delay until the start of immunotherapy after disease onset $(>60$ days, $\mathrm{n}=28 / 41$ ) had a higher mRS at 6 and 12 months (mRS 3 [IQR 2-3] vs mRS 2 [IQR 1-2], $p=0.012$; and mRS 2 [IQR $2-3$ ] vs mRS 1 [IQR $1-2], p=0.027$, respectively). Similarly, more cognitive problems remained after 6 months in those treated later ( $96 \%$ vs $67 \%, p=0.02$ ), whereas a similar trend was seen at 12 months of follow-up ( $92 \%$ vs $67 \%, p=0.10$ ).

Patients improved after therapy indicated by a lower mRS score after treatment (median mRS 2; 67\% ADL independent). Only in anti-GABA $A_{B} R$ encephalitis, patients tended to remain dependent more frequently, whereas in the other AIE subtypes the majority became independent ( $p_{\text {un- }}$ corrected $=0.019)$. Cognitive deficits were still present after 12 months in most patients (81\%) and were similar between AIE subtypes. In total, encephalitis relapses were seen in $11 \mathrm{pa}-$ tients (17\%), and 14 patients had died (22\%).

\section{Discussion}

This nationwide observational cohort study evaluated cognitive characteristics in middle-aged or older patients with anti-LGI1, anti-NMDAR, anti-GABA ${ }_{B} R$, and anti-CASPR2 encephalitis. We show that AIE can resemble dementia frequently, especially as RPD. Ancillary testing can be misleading, lacking an inflammatory signature (in the CSF or on brain MRI), whereas the CSF biomarker profile that is often requested for dementia workup might mimic a neurodegenerative syndrome. Seizures are often present both early and late in the disease course. These can be very subtle and therefore easily overlooked. 


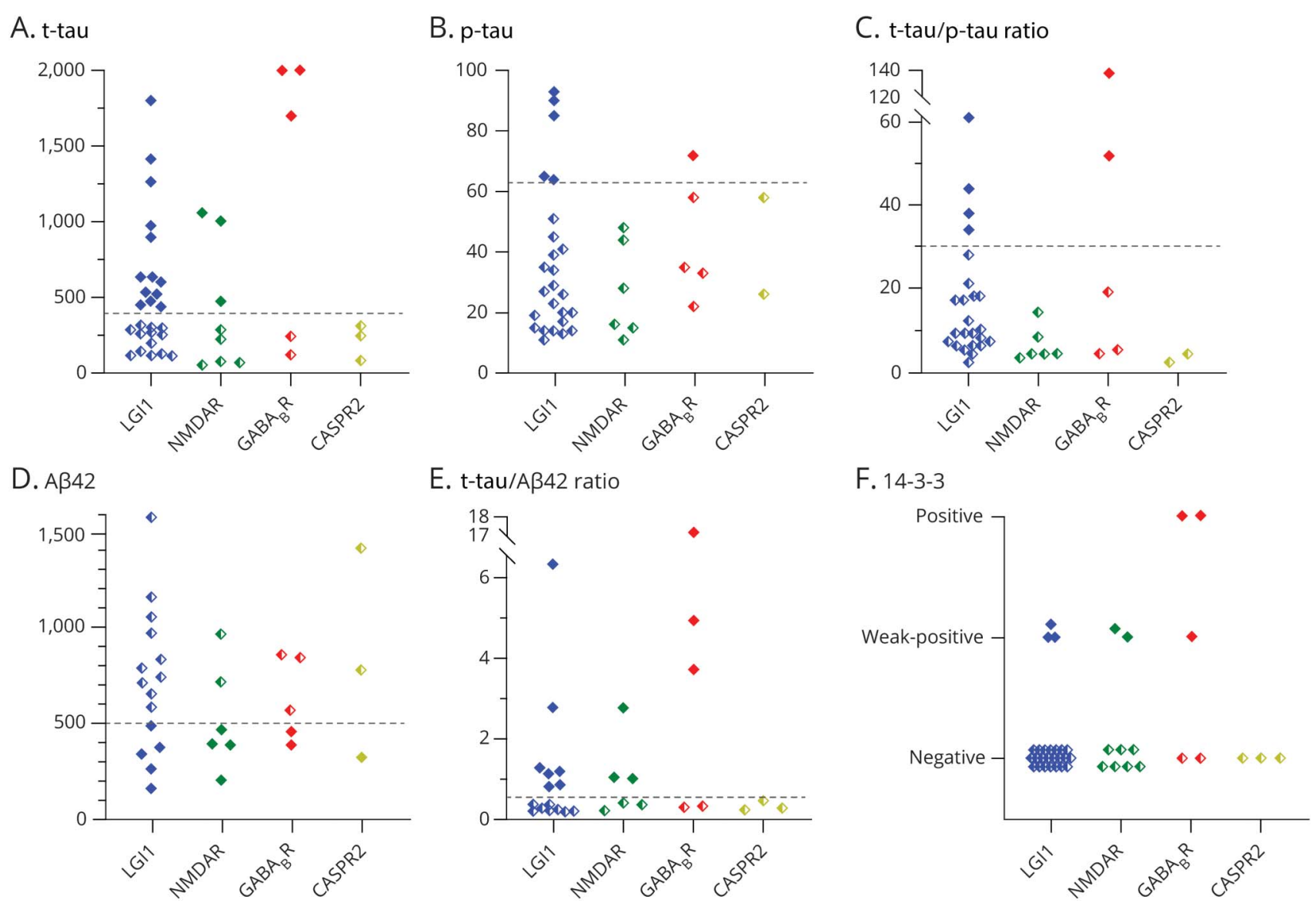

Dementia CSF biomarkers in 44 patients with autoimmune encephalitis cutoff values to be considered abnormal were (A) t-tau $>400 \mathrm{pg} / \mathrm{mL}$, (B) p-tau $>64 \mathrm{pg} /$ $\mathrm{mL}$, (C) a t-tau/p-tau ratio of $>30$, (D) A $342<500 \mathrm{pg} / \mathrm{mL}$, and (E) a t-tau/AB42 ratio of $>0.52$. (F) A positive 14-3-3 is abnormal. Two patients with t-tau values of 14,720 and 2,800 were maximized at 2001. Five patients with a positive 14-3-3 had been tested by RT-QulC, all negative. Filled diamond symbols represent abnormal results, and half-filled symbols represent normal results. $A \beta 42=$ amyloid-beta-42; CASPR2 = contactin-associated protein-like 2; GABA $\mathrm{B}=$ gammaaminobutyric acid B receptor; $\mathrm{LGl}$ = leucine-rich glioma-inactivated 1; NMDAR = NMDA receptor; $\mathrm{p}$-tau = phosphorylated tau; RT-QuIC = real-time quakinginduced conversion; t-tau = total tau.

Our study shows that a neurodegenerative dementia syndrome is frequently suspected initially in patients with AIE. The cognitive deterioration has a rapidly progressive character in most patients, which is much larger than the prevalence of RPD in reported studies of dementia cohorts $(4 \%-30 \%))^{23-25}$ Literature on pure cognitive decline in patients with antineuronal autoantibodies is sparse, ${ }^{26,27}$ and in our experience, many patients with RPD are not investigated for neuronal autoantibodies. Our results emphasize that part of the (older) patients with a possible dementia diagnosis should be tested for extracellular neuronal antibodies. In all AIE subtypes, we identified patients with cognitive deterioration fulfilling the criteria for dementia. Encephalitis with anti-LGI1 antibodies is the most common subtype in this age category, and the clinical picture mimics dementia most often. Fewer patients with antiNMDAR encephalitis were included in this study, as this disease predominantly affects young adults. ${ }^{28}$ Patients with anti-GABA $A_{B} R$ encephalitis are characterized by severe seizures in many ${ }^{29}$ but can present as RPD. ${ }^{5}$ Most patients with antiCASPR2 encephalitis had other symptoms, such as (painful) polyneuropathy, cerebellar dysfunction, or epilepsy. ${ }^{4}$ AntiIgLON5 encephalopathy has broad clinical phenotypes, including manifestations that can resemble dementia, ${ }^{30}$ but as this disease is still evolving, we have not included these patients. Anti-AMPAR can occasionally present with cognitive decline without other symptoms but is very rare. ${ }^{31}$ Similarly, a recent publication also showed the even rarer AK5 antibodies to be associated frequently with cognitive decline, although MRI and CSF testing was very abnormal in almost all. ${ }^{32}$

Seizures are generally better known within AIE and less likely in dementia, although $10 \%-22 \%$ of early-onset $\mathrm{AD}$ patients develop seizures in all disease stages. ${ }^{33}$ Our study shows that a high percentage ( $\sim$ two-third of the cohort) developed seizures, despite (arbitrarily) excluding patients with prominent seizures within the first 4 weeks. The seizures within this study appeared late in the disease course or were subtle seizures (FBDS or nonmotor subtle focal seizures), often overlooked. Altogether, it indicates that seizures are an important red flag differentiating between a possible AIE when patients present 
Table 2 Treatment and Outcome

\begin{tabular}{|c|c|c|c|c|c|}
\hline & Total & LGI1 $(n=42)$ & NMDAR $(n=13)$ & $\mathrm{GABA}_{B} \mathrm{R}(\mathrm{n}=8)$ & $p$ Value $^{a}$ \\
\hline \multicolumn{6}{|l|}{ Immune therapy } \\
\hline Days to immunotherapy after disease onset & $99(32-219,2-5,080)$ & $110(38-258,2-5,080)$ & $56(18-148,7-427)$ & $29(22-46,15-63)$ & 0.13 \\
\hline First-line immunotherapy & $59(94)$ & $42(100)$ & $13(100)$ & $4(50)^{b}$ & $<0.0001 * * *$ \\
\hline IV methylprednisolone & $52(83)$ & $36(86)$ & $12(92)$ & $4(50)$ & 0.055 \\
\hline IV immunoglobulins & $43(68)$ & $29(69)$ & $12(92)$ & $2(25)$ & $0.006^{*}$ \\
\hline Second-line immunotherapy & $9(14)$ & $2(5)$ & $5(39)$ & $2(25)$ & $0.005 * \star$ \\
\hline Rituximab & $7(11)$ & $2(5)$ & $3(23)$ & $2(25)$ & 0.057 \\
\hline Cyclophosphamide & $4(6)$ & $0(0)$ & $3(23)$ & $1(13)$ & $0.010 *$ \\
\hline \multicolumn{6}{|l|}{ Evolution } \\
\hline ICU & $10(16)$ & $3(7)$ & $6(46)$ & $1(13)$ & $0.004 * *$ \\
\hline mRS at onset & $3(3-4,2-5)$ & $3(3-4,2-5)$ & $4(3-5,3-5)$ & $4(3-5,2-5)$ & 0.086 \\
\hline $0-2$ & $2(3)$ & $1(2)$ & 0 & $1(14)$ & \\
\hline $3-5$ & $61(97)$ & $41(98)$ & $13(100)$ & $7(86)$ & \\
\hline Best mRS after treatment $(n=63)$ & $2(1-3,0-5)$ & $2(1-3,0-4)$ & $2(1-4,0-5)$ & $3(2-4,2-5)$ & $0.019 *$ \\
\hline $0-2$ & $42(67)$ & $31(74)$ & $9(69)$ & $2(25)$ & \\
\hline $3-5$ & $21(33)$ & $11(26)$ & $4(31)$ & $6(75)$ & \\
\hline Cognitive complaints 6 mo after onset & $47 / 55(86)$ & $35 / 40(88)$ & $6 / 9(67)$ & $6 / 6(100)$ & 0.19 \\
\hline mRS 6 mo after onset $(n=59)$ & $3(2-3,0-6)$ & $2(2-3,1-4)$ & $3(2-6,0-6)$ & $4(3-6,2-6)$ & $0.048^{*}$ \\
\hline $0-2$ & $28(47)$ & $21(53)$ & $6(50)$ & $1(13)$ & \\
\hline $3-5$ & $26(44)$ & $19(47)$ & $3(25)$ & $4(57)$ & \\
\hline 6 & $5(8)$ & 0 & $3(25)$ & $2(29)$ & \\
\hline Cognitive complaints $12 \mathrm{mo}$ after onset & $38 / 47(81)$ & $29 / 34(85)$ & $4 / 8(50)$ & $5 / 5(100)$ & 0.058 \\
\hline mRS 12 mo after onset $(n=53)$ & $2(2-3,0-6)$ & $2(1-3,0-6)$ & $2(1-6,0-6)$ & $3(3-6,2-6)$ & 0.057 \\
\hline $0-2$ & $27(51)$ & $20(57)$ & $6(55)$ & $1(13)$ & \\
\hline $3-5$ & $20(38)$ & $14(40)$ & $2(18)$ & $4(57)$ & \\
\hline 6 & $6(11)$ & $1(3)$ & $3(27)$ & $2(29)$ & \\
\hline Cognitive complaints at the last FU & $44 / 57(77)$ & $33 / 41(81)$ & $4 / 9(44)$ & $7 / 7(100)$ & $0.020^{*}$ \\
\hline Months FU & $16(9-25,1-164)$ & $18(11-25,3-164)$ & $24(10-32,3-71)$ & $12(3-22,1-39)$ & 0.37 \\
\hline Relapse & $11(17)$ & $9(21)$ & $2(15)$ & 0 & 0.27 \\
\hline Death & $14(22)$ & $5(12)$ & $4(31)$ & $5(63)$ & $0.042^{*}$ \\
\hline
\end{tabular}

Abbreviations: FU = follow-up; GABA $\mathrm{R}=$ gamma-aminobutyric acid $\mathrm{B}$ receptor; ICU = intensive care unit; LGI1 = leucine-rich glioma-inactivated 1; $\mathrm{mRS}=$ modified Rankin scale; NMDAR = NMDA receptor.

Data are $\mathrm{n}(\%), \mathrm{n} / \mathrm{n}(\%)$, or median (interquartile range; range).

${ }^{*} p<0.05, * * p<0.005$, and $* * * p<0.0005$.

a Only $p$ values $<0.005$ were considered relevant.

${ }^{b}$ Two patients who did not receive first-line immunotherapy received chemotherapy.

with dementia symptoms. There should be more awareness for FBDS and nonmotor focal seizures because missing leads to a delay, incorrect diagnosis, and more important inadvertently withholding of immunotherapy resulting in worse outcomes, ${ }^{3,6}$ also seen in our cohort. These subtle seizures were almost exclusively seen in anti-LGI1 encephalitis. FBDS, 1 subtype, are known to be pathognomonic for anti-LGI1 encephalitis and are defined as frequent attacks ( $>8$ per day) lasting less than 30 seconds with a dystonic posture of the arm, often combined with a facial contraction. ${ }^{34}$ 
Frequently, ancillary testing showed no clues suggesting an autoimmune etiology: no abnormalities in the CSF (e.g., pleocytosis) or no typical mesiotemporal hyperintensities on brain MRI, consistent with previous studies. ${ }^{1,26,35}$ Patients with LGI1 or CASPR2 antibodies had more frequently normal CSF results, also in line with previous studies. ${ }^{4,36}$ In addition, EEG results were normal or only showing some encephalopathy in many patients with AIE, similar to patterns seen in patients with neurodegenerative dementia. Noteworthy, regular ictal EEG generally shows no abnormalities during FBDS. Similarly, EEG is unrevealing if patients have an epileptic focus deep in the temporal lobe. ${ }^{37,38}$ Finally, tumors can be present in AIE, but in general, patients are only screened for tumors after antibody positivity. Therefore, in clinical practice, this rarely points toward an autoimmune etiology in patients with cognitive deterioration. Differentiating between AIE and a neurodegenerative cause becomes more complex when CSF markers that are often requested when dementia is suspected are abnormal. In almost half of our tested AIE patients (in whom $A \beta 42$ was also tested), the combination of biomarkers was fitting a neurodegenerative dementia profile. Few cases had positive 14-3-3 results, sometimes attributed to CJD, but none had abnormalities on MRI-DWI. Unfortunately, we did not have data to evaluate the discriminatory value of FDG-PET. A selection of the 14-33 positive samples was analyzed by RT-QuIC, considered a more specific marker for CJD, and all had negative test results confirming the higher specificity compared with 14-3-3. ${ }^{39}$ Some of the CSF markers are known to be not highly specific for dementia (t-tau and 14-3-3), as these represent neuronal injury. The explanation for abnormal A $\beta 42$ is currently unknown. Although we cannot exclude that patients were developing concomitant $\mathrm{AD}$, the improvement to immunotherapy and lack of cognitive deterioration over time, despite extended follow-up, make this highly improbable. Overall, physicians should be aware that ancillary testing can be deceivingly normal in many cases, and dementia biomarkers can be "falsely" positive. IgG index and oligoclonal bands in the CSF can be helpful and should be routinely tested to investigate an autoimmune etiology.

The dementia syndrome shows distinctive cognitive profiles in different AIE subtypes. Both anti-LGI1 and anti-GABA ${ }_{B} R$ encephalitis are associated with visuospatial and executive dysfunction. This is consistent with cognitive dysfunction seen in dementia with Lewy bodies, ${ }^{40}$ and the regularly accompanied hallucinations and sleep problems are also known in AIE. Anti-NMDAR encephalitis is more reminiscent of frontotemporal dementia because language impairments and behavioral problems are more prominent in both diseases. $^{41,42}$ Contrary to neurodegenerative dementia syndromes, patients with AIE can be treated and generally respond well to immunotherapy. In this study looking at elderly patients with AIE, in which most were initially suspected of having an untreatable dementia syndrome, many patients improved with immunotherapy. This improvement was seen despite the relatively long delay until treatment (median 99 days). This delay is witness to the difficulties in diagnosing
AIE in older patients, as shown for anti-NMDAR encephalitis. ${ }^{8}$ Nevertheless, patients became independent in their daily activities again (best $\mathrm{mRS}$ after treatment $\leq 2$ ). However, better treatments and targeted guidance are necessary to reduce long-lasting cognitive dysfunction because a high percentage of patients in all subtypes of AIE still experience problems 1 year after disease onset. Research evaluating neuropsychological assessments is still sparse. ${ }^{3,13,43}$ In patients with anti-LGI1 encephalitis, long-term cognitive deficits were attributed to hippocampal damage ${ }^{43}$ and to reduced connectivity in anti-NMDAR encephalitis, ${ }^{44}$ but direct links with poorer cognitive recovery are needed.

Although this study is nationwide, including 4 types of AIE, there are some limitations associated with the retrospective design of this study. First, detailed cognitive symptoms were not always accurately documented, especially during followup. Second, because of the low incidence of anti-GABA $R$ and anti-CASPR2 encephalitis and because of our restrictive selection criteria (mainly for anti-NMDAR and anti-CASPR2 encephalitis), we describe modest group sizes, especially compared with anti-LGI1 encephalitis. A large study examining antibodies in unselected patients with presumed dementia, without suspicion of autoimmunity, as well as patients with RPD would be most useful to consolidate our findings.

In conclusion, AIE can mimic dementia. Antibody testing should be considered more often and sooner in the disease course, especially if red flags are present. Red flags for AIE in patients aged 45 years or older are a rapidly progressive cognitive decline, abnormalities in ancillary testing (inflammatory changes in the CSF or on MRI), easily missed subtle seizures early in the disease course, and prominent seizures later in the disease. Extensive brain atrophy early in the disease course argues in favor of neurodegeneration, whereas abnormalities on MRI-DWI are more suggestive for CJD in patients with RPD. CSF markers that are often requested when dementia is suspected (including $\mathrm{t}$-tau, $\mathrm{p}$-tau, $\mathrm{A} \beta 42$, and 14-3-3) can be positive in AIE. However, physicians should be aware that ancillary testing of the CSF and brain MRI can be entirely normal in AIE, necessitating antibody testing when in doubt.

\section{Acknowledgment}

The authors thank all patients for their participation, and they thank all referring physicians. The authors thank Esther Hulsenboom and Mariska Nagtzaam for their technical assistance. M.W.J. Schreurs, P.A.E. Sillevis Smitt, J.M. de Vries, and M.J. Titulaer of this publication are members of the European Reference Network for Rare Immunodeficiency, Autoinflammatory and Autoimmune Diseases-Project ID No. 739543 (ERN-RITA).

\section{Study Funding}

M.J. Titulaer was supported by an Erasmus MC fellowship and has received funding from the Netherlands Organization for Scientific Research (NWO, Veni incentive), ZonMw 
(Memorabel program), and the Dutch Epilepsy Foundation (NEF 14-19 and 19-08).

\section{Disclosure}

A.E.M. Bastiaansen, R.W. van Steenhoven, M.A.A.M. de Bruijn, Y.S. Crijnen, A. van Sonderen, M.H. van Coevorden-Hameete, and M.M. Nühn report no disclosures relevant to the manuscript. M.M. Verbeek receives grant support from the NIH, USA (CAFÉ project, grant number 5R01NS104147-02), the Selfridges Group Foundation, and the BIONIC project (no. 733050822), which has been made possible by ZonMw. The BIONIC project is part of "Memorabel," the research and innovation program for dementia, as part of the Dutch national "Deltaplan for Dementia": zonmw.nl/dementiaresearch. M.W.J. Schreurs reports no disclosures relevant to the manuscript. P.A.E. Sillevis Smitt holds a patent for the detection of antiDNER and received research support from Euroimmun. J.M. de Vries and F.J. de Jong report no disclosures relevant to the manuscript. M.J. Titulaer has filed a patent, on behalf of the Erasmus MC, for methods for typing neurologic disorders and cancer, and devices for use therein, and has received research funds for serving on a scientific advisory board of MedImmune LLC, for consultation at Guidepoint Global LLC, for consultation at UCB, and for teaching colleagues by Novartis. M.J. Titulaer has received an unrestricted research grant from Euroimmun AG and from CSL Behring. Go to Neurology.org/NN for full disclosures.

\section{Publication History}

Received by Neurology: Neuroimmunology \& Neuroinflammation February 25, 2021. Accepted in final form May 19, 2021.

Appendix Authors

\begin{tabular}{lll}
\hline Name & Location & Contribution \\
\hline $\begin{array}{l}\text { Anna E.M. } \\
\text { Bastiaansen, MD }\end{array}$ & $\begin{array}{l}\text { Erasmus MC University } \\
\text { Medical Center, } \\
\text { Rotterdam, the } \\
\text { Netherlands }\end{array}$ & $\begin{array}{l}\text { Study design, acquisition of } \\
\text { data, statistical analysis, } \\
\text { interpretation of data, and } \\
\text { draft of the manuscript }\end{array}$ \\
\hline $\begin{array}{l}\text { Robin W. van } \\
\text { Steenhoven, MD }\end{array}$ & $\begin{array}{l}\text { Erasmus MC University } \\
\text { Medical Center, } \\
\text { Rotterdam and VU } \\
\text { University Medical Center }\end{array}$ & $\begin{array}{l}\text { Acquisition of data and } \\
\text { revision of the manuscript } \\
\text { for content }\end{array}$ \\
& $\begin{array}{l}\text { Amsterdam, the } \\
\text { Netherlands }\end{array}$ & \\
\hline $\begin{array}{l}\text { Marienke A.A.M. } \\
\text { de Bruijn, MD }\end{array}$ & $\begin{array}{l}\text { Elisabeth Tweesteden } \\
\text { Medical Center, Tilburg, }\end{array}$ & $\begin{array}{l}\text { Acquisition of data and } \\
\text { revision of the manuscript } \\
\text { for content }\end{array}$ \\
\hline $\begin{array}{l}\text { Yvette S. Crijnen } \\
\text { MD }\end{array}$ & $\begin{array}{l}\text { Erasmus MC University } \\
\text { Medical Center, }\end{array}$ & $\begin{array}{l}\text { Acquisition of data and } \\
\text { revision of the manuscript } \\
\text { for content }\end{array}$ \\
& $\begin{array}{l}\text { Rotterdam, the } \\
\text { Netherlands }\end{array}$ & \\
\hline $\begin{array}{l}\text { Agnes van } \\
\text { Sonderen, MD, } \\
\text { PhD }\end{array}$ & $\begin{array}{l}\text { Haaglanden Medical } \\
\text { Center, The Hague, the }\end{array}$ & $\begin{array}{l}\text { Acquisition of data and } \\
\text { revision of the manuscript } \\
\text { for content }\end{array}$ \\
\hline $\begin{array}{l}\text { Marleen H. van } \\
\text { Coevorden- } \\
\text { Hameete, MD, } \\
\text { PhD }\end{array}$ & $\begin{array}{l}\text { Erasmus MC University } \\
\text { Medical Center, } \\
\text { Rotterdam, the } \\
\text { Netherlands }\end{array}$ & $\begin{array}{l}\text { Acquisition of data and } \\
\text { revision of the manuscript } \\
\text { for content }\end{array}$ \\
\hline
\end{tabular}

Appendix (continued)

\begin{tabular}{|c|c|c|}
\hline Name & Location & Contribution \\
\hline $\begin{array}{l}\text { Marieke M. } \\
\text { Nühn, MSc }\end{array}$ & $\begin{array}{l}\text { University Utrecht, the } \\
\text { Netherlands }\end{array}$ & $\begin{array}{l}\text { Acquisition of data and } \\
\text { revision of the manuscript } \\
\text { for content }\end{array}$ \\
\hline $\begin{array}{l}\text { Marcel M. } \\
\text { Verbeek, PhD }\end{array}$ & $\begin{array}{l}\text { Radboud University } \\
\text { Medical Center, } \\
\text { Nijmegen, the } \\
\text { Netherlands }\end{array}$ & $\begin{array}{l}\text { Acquisition of data and } \\
\text { revision of the manuscript } \\
\text { for content }\end{array}$ \\
\hline $\begin{array}{l}\text { Marco W.J. } \\
\text { Schreurs, PhD }\end{array}$ & $\begin{array}{l}\text { Erasmus MC University } \\
\text { Medical Center, } \\
\text { Rotterdam, the } \\
\text { Netherlands }\end{array}$ & $\begin{array}{l}\text { Acquisition of data and } \\
\text { revision of the manuscript } \\
\text { for content }\end{array}$ \\
\hline $\begin{array}{l}\text { Peter A.E. Sillevis } \\
\text { Smitt, MD, PhD }\end{array}$ & $\begin{array}{l}\text { Erasmus MC University } \\
\text { Medical Center, } \\
\text { Rotterdam, the } \\
\text { Netherlands }\end{array}$ & $\begin{array}{l}\text { Acquisition of data and } \\
\text { revision of the manuscript } \\
\text { for content }\end{array}$ \\
\hline $\begin{array}{l}\text { Juna M. de Vries, } \\
\text { MD, PhD }\end{array}$ & $\begin{array}{l}\text { Erasmus MC University } \\
\text { Medical Center, } \\
\text { Rotterdam, the } \\
\text { Netherlands }\end{array}$ & $\begin{array}{l}\text { Acquisition of data and } \\
\text { revision of the manuscript } \\
\text { for content }\end{array}$ \\
\hline $\begin{array}{l}\text { Frank Jan de } \\
\text { Jong, MD, PhD }\end{array}$ & $\begin{array}{l}\text { Erasmus MC University } \\
\text { Medical Center, } \\
\text { Rotterdam, the } \\
\text { Netherlands }\end{array}$ & $\begin{array}{l}\text { Interpretation of data and } \\
\text { revision of the manuscript } \\
\text { for content }\end{array}$ \\
\hline $\begin{array}{l}\text { Maarten J. } \\
\text { Titulaer, MD, } \\
\text { PhD }\end{array}$ & $\begin{array}{l}\text { Erasmus MC University } \\
\text { Medical Center, } \\
\text { Rotterdam, the } \\
\text { Netherlands }\end{array}$ & $\begin{array}{l}\text { Study design, study } \\
\text { supervision, interpretation } \\
\text { of data, statistical analysis, } \\
\text { and revision of the } \\
\text { manuscript for content }\end{array}$ \\
\hline
\end{tabular}

\section{References}

1. Graus F, Titulaer MJ, Balu R, et al. A clinical approach to diagnosis of autoimmune encephalitis. Lancet Neurol. 2016;15(4):391-404.

2. Titulaer MJ, McCracken L, Gabilondo I, et al. Treatment and prognostic factors for long-term outcome in patients with anti-NMDA receptor encephalitis: an observational cohort study. Lancet Neurol. 2013;12(2):157-165

3. van Sonderen A, Thijs RD, Coenders EC, et al. Anti-LGIl encephalitis: clinical syndrome and long-term follow-up. Neurology. 2016;87(14):1449-1456.

4. van Sonderen A, Arino H, Petit-Pedrol M, et al. The clinical spectrum of Caspr2 antibody-associated disease. Neurology. 2016;87(5):521-528.

5. van Coevorden-Hameete MH, de Bruijn M, de Graaff E, et al. The expanded clinical spectrum of anti-GABABR encephalitis and added value of KCTD16 autoantibodies. Brain. 2019;142(6):1631-1643.

6. Arino H, Armangue T, Petit-Pedrol M, et al. Anti-LGI1-associated cognitive impairment: presentation and long-term outcome. Neurology. 2016;87(8):759-765.

7. Maat P, de Beukelaar JW, Jansen C, et al. Pathologically confirmed autoimmune encephalitis in suspected Creutzfeldt-Jakob disease. Neurol Neuroimmunol Neuroinflamm. 2015;2(6):e178.

8. Titulaer MJ, McCracken L, Gabilondo I, et al. Late-onset anti-NMDA receptor encephalitis. Neurology. 2013;81(12):1058-1063.

9. Geschwind MD, Tan KM, Lennon VA, et al. Voltage-gated potassium channel autoimmunity mimicking Creutzfeldt-Jakob disease. Arch Neurol. 2008;65(10):1341-1346.

10. Grau-Rivera O, Sanchez-Valle R, Saiz A, et al. Determination of neuronal antibodies in suspected and definite Creutzfeldt-Jakob disease. JAMA Neurol. 2014;71(1):74-78.

11. Baumgartner A, Rauer S, Hottenrott $\mathrm{T}$, et al. Admission diagnoses of patients later diagnosed with autoimmune encephalitis. J Neurol. 2019;266(1):124-132.

12. Flanagan EP, McKeon A, Lennon VA, et al. Autoimmune dementia: clinical course and predictors of immunotherapy response. Mayo Clin Proc. 2010;85(10):881-897.

13. de Bruijn M, Aarsen FK, van Oosterhout MP, et al. Long-term neuropsychological outcome following pediatric anti-NMDAR encephalitis. Neurology. 2018;90(22): e1997-e2005.

14. Ances BM, Vitaliani R, Taylor RA, et al. Treatment-responsive limbic encephalitis identified by neuropil antibodies: MRI and PET correlates. Brain. 2005;128(pt 8) 1764-1777.

15. Gresa-Arribas N, Titulaer MJ, Torrents A, et al. Antibody titres at diagnosis and during follow-up of anti-NMDA receptor encephalitis: a retrospective study. Lancet Neurol. 2014;13(2):167-177.

16. Herbert MK, Eeftens JM, Aerts MB, et al. CSF levels of DJ-1 and tau distinguish MSA patients from PD patients and controls. Parkinsonism Relat Disord. 2014;20(1): $112-115$. 
17. van Eijk JJ, van Everbroeck B, Abdo WF, Kremer BP, Verbeek MM. CSF neurofilament proteins levels are elevated in sporadic Creutzfeldt-Jakob disease. J Alzheimers Dis. 2010;21(2):569-576.

18. McGuire LI, Peden AH, Orru CD, et al. Real time quaking-induced conversion analysis of cerebrospinal fluid in sporadic Creutzfeldt-Jakob disease. Ann Neurol. 2012;72(2):278-285.

19. Duits FH, Teunissen CE, Bouwman FH, et al. The cerebrospinal fluid "Alzheimer profile”: easily said, but what does it mean? Alzheimers Dement. 2014;10(6):713-723.e2.

20. McKhann GM, Knopman DS, Chertkow H, et al. The diagnosis of dementia due to Alzheimer's disease: recommendations from the National Institute on AgingAlzheimer's Association workgroups on diagnostic guidelines for Alzheimer's disease. Alzheimers Dement. 2011;7(3):263-269.

21. Geschwind MD. Rapidly progressive dementia. Continuum (Minneap Minn). 2016; 22(2 dementia):510-537.

22. van Swieten JC, Koudstaal PJ, Visser MC, Schouten HJ, van Gijn J. Interobserver agreement for the assessment of handicap in stroke patients. Stroke. 1988;19(5): 604-607.

23. Schmidt C, Wolff M, Weitz M, et al. Rapidly progressive Alzheimer disease. Arch Neurol. 2011;68(9):1124-1130.

24. Studart Neto A, Soares Neto HR, Simabukuro MM, et al. Rapidly progressive dementia: prevalence and causes in a neurologic unit of a tertiary hospital in Brazil. Alzheimer Dis Assoc Disord. 2017;31(3):239-243.

25. Anuja P, Venugopalan V, Darakhshan N, et al. Rapidly progressive dementia: an eight year (2008-2016) retrospective study. PLoS One. 2018;13(1):e0189832.

26. Escudero D, Guasp M, Arino H, et al. Antibody-associated CNS syndromes without signs of inflammation in the elderly. Neurology. 2017;89(14):1471-1475.

27. Geschwind MD, Haman A, Miller BL. Rapidly progressive dementia. Neurol Clin. 2007;25(3):783-807, vii.

28. Dalmau J, Gleichman AJ, Hughes EG, et al. Anti-NMDA-receptor encephalitis: case series and analysis of the effects of antibodies. Lancet Neurol. 2008;7(12):1091-1098.

29. Lancaster E, Lai M, Peng X, et al. Antibodies to the GABA(B) receptor in limbic encephalitis with seizures: case series and characterisation of the antigen. Lancet Neurol. 2010;9(1):67-76.

30. Gaig C, Graus F, Compta Y, et al. Clinical manifestations of the anti-IgLON5 disease. Neurology. 2017;88(18):1736-1743.
31. Joubert B, Kerschen P, Zekeridou A, et al. Clinical spectrum of encephalitis associated with antibodies against the alpha-amino-3-hydroxy-5-methyl-4-isoxazolepropionic acid receptor: case series and review of the literature. JAMA Neurol. 2015;72(10): 1163-1169.

32. Muniz-Castrillo S, Hedou JJ, Ambati A, et al. Distinctive clinical presentation and pathogenic specificities of anti-AK5 encephalitis. Brain. 2021;2021:awab153.

33. Vossel KA, Tartaglia MC, Nygaard HB, Zeman AZ, Miller BL. Epileptic activity in Alzheimer's disease: causes and clinical relevance. Lancet Neurol. 2017;16(4):311-322.

34. Irani SR, Michell AW, Lang B, et al. Faciobrachial dystonic seizures precede Lgil antibody limbic encephalitis. Ann Neurol. 2011;69(5):892-900.

35. Hebert J, Gros P, Lapointe S, et al. Searching for autoimmune encephalitis: beware of normal CSF. J Neuroimmunol. 2020;345:577285.

36. Jarius S, Hoffmann L, Clover L, Vincent A, Voltz R. CSF findings in patients with voltage gated potassium channel antibody associated limbic encephalitis. J Neurol Sci. 2008;268(1-2):74-77.

37. Schmitt SE, Pargeon K, Frechette ES, et al. Extreme delta brush: a unique EEG pattern in adults with anti-NMDA receptor encephalitis. Neurology. 2012;79(11):1094-1100.

38. Navarro V, Kas A, Apartis E, et al. Motor cortex and hippocampus are the two main cortical targets in LGI1-antibody encephalitis. Brain. 2016;139(pt 4):1079-1093.

39. Fairfoul G, McGuire LI, Pal S, et al. Alpha-synuclein RT-QuIC in the CSF of patients with alpha-synucleinopathies. Ann Clin Transl Neurol. 2016;3(10):812-818.

40. McKeith IG, Boeve BF, Dickson DW, et al. Diagnosis and management of dementia with Lewy bodies: fourth consensus report of the DLB Consortium. Neurology. 2017; 89(1):88-100.

41. Rascovsky K, Hodges JR, Knopman D, et al. Sensitivity of revised diagnostic criteria for the behavioural variant of frontotemporal dementia. Brain. 2011;134(pt 9): 2456-2477.

42. Gorno-Tempini ML, Hillis AE, Weintraub S, et al. Classification of primary progressive aphasia and its variants. Neurology. 2011;76(11):1006-1014.

43. Finke C, Pruss $\mathrm{H}$, Heine J, et al. Evaluation of cognitive deficits and structural hippocampal damage in encephalitis with leucine-rich, glioma-inactivated 1 antibodies. JAMA Neurol. 2017;74(1):50-59.

44. Finke C, Kopp UA, Scheel M, et al. Functional and structural brain changes in anti-Nmethyl-D-aspartate receptor encephalitis. Ann Neurol. 2013;74(2):284-296. 


\section{Neurology \\ Neuroimmunology \& Neuroinflammation}

Autoimmune Encephalitis Resembling Dementia Syndromes

Anna E.M. Bastiaansen, Robin W. van Steenhoven, Marienke A.A.M. de Bruijn, et al.

Neurol Neuroimmunol Neuroinflamm 2021;8;

DOI 10.1212/NXI.0000000000001039

This information is current as of August 2, 2021

\section{Updated Information \& Services}

References

Subspecialty Collections

Permissions \& Licensing

Reprints including high resolution figures, can be found at:

http://nn.neurology.org/content/8/5/e1039.full.html

This article cites 44 articles, 2 of which you can access for free at: http://nn.neurology.org/content/8/5/e1039.full.html\#\#ref-list-1

This article, along with others on similar topics, appears in the following collection(s):

All Cognitive Disorders/Dementia

http://nn.neurology.org//cgi/collection/all_cognitive_disorders_dementi a

Autoimmune diseases

http://nn.neurology.org//cgi/collection/autoimmune_diseases

Encephalitis

http://nn.neurology.org//cgi/collection/encephalitis

Information about reproducing this article in parts (figures,tables) or in its entirety can be found online at:

http://nn.neurology.org/misc/about.xhtml\#permissions

Information about ordering reprints can be found online:

http://nn.neurology.org/misc/addir.xhtml\#reprintsus

Neurol Neuroimmunol Neuroinflamm is an official journal of the American Academy of Neurology.

Published since April 2014, it is an open-access, online-only, continuous publication journal. Copyright

Copyright (C) 2021 The Author(s). Published by Wolters Kluwer Health, Inc. on behalf of the American

Academy of Neurology.. All rights reserved. Online ISSN: 2332-7812.

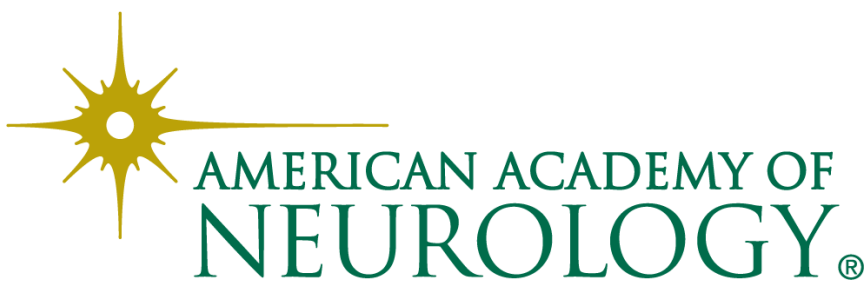

